\title{
Perbedaan Tingkat Activity of Daily Living (ADL) antara Lansia Aktif dengan Lansia Tidak Aktif Melakukan Kunjungan ke Posyandu Lansia
}

\author{
Maria Srisuharny $^{a}$, Maria Diyah ${ }^{b}$, Erni Yohani Mahtuti ${ }^{a}$ \\ aprodi Sarjana Keperawatan, STIKes Maharani, Malang, Indonesia \\ bProdi Sarjana Keperawatan, Poltekes Kemenkes, Malang, Indonesia \\ aProdi Analis Kesehatan, STIKes Maharani, Malang, Indonesia \\ Email Korespondensi: surnii.nenta@gmail.com
}

\begin{abstract}
Introduction: The increasing age of a person will be followed by various changes that affect physical and psychological conditions. The older the person's age, the more it decreases his physical ability. It causes the elderly to become dependent on others, including in fulfilling the needs of his daily activities. Activity of Daily Living (ADL) is a form of measurement of a person's ability to perform daily activities independently that includes bathing, eating, toileting, continent, dressing, and moving. This research aims to determine the difference in daily activity level between active elderlies and the elderlies who did not actively visit the elderly Posyandu in Kelurahan Tunggulwulung District Lowokwaru. Method: This study uses observational methods with cross sectional approach. Research samples were 50 respondents (25 active elderlies and 25 inactive elderlies). This study used purposive quota sampling techniques with Chi-Square test as the data analysis. Results: From the results, it was obtained the value $\rho$ : 0.006; $\alpha$ : 0.05. Because $\rho<\alpha$ then Ho is rejected means there is a significant difference in the activity level of daily living between active elderlies and the elderlies who did not actively visit the elderly Posyandu. Conclusions: The results of this research are expected to provide motivation to the elderlies to visit the elderly Posyandu as a form of activity to control, maintain, and improve the health of the elderly that was held every 1 month in local posyandu.
\end{abstract}

Keywords: Activity of Daily Living (ADL), elderly, elderly Posyandu

\begin{abstract}
Abstrak
Pendahuluan: Bertambahnya usia seseorang akan diikuti oleh berbagai perubahan yang akan mempengaruhi kondisi fisik dan psikologis. Semakin tua umur seseorang, maka akan semakin menurun kemampuan fisiknya. Hal ini menyebabkan lansia menjadi tergantung pada orang lain, termasuk dalam memenuhi kebutuhan aktivitas sehari-harinnya. Activity of Daily Living $(A D L)$ adalah suatu bentuk pengukuran kemampuan seseorang untuk melakukan kegiatan
\end{abstract}




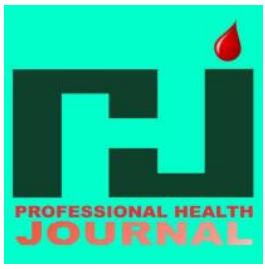

PROFESIONAL HEALTH JOURNAL

Volume 1, No. 2, Juni 2020 (Hal. 58-64)

Available Online at https://www.ojsstikesbanyuwangi.com

sehari-harinya secara mandiri yang meliputi mandi, makan, toileting, kontinen, berpakaian, dan berpindah. Penelitian ini bertujuan untuk mengetahui perbedaan tingkat Activity of Daily Living antara lansia aktif dengan lansia tidak aktif melakukan kunjungan ke posyandu lansia di Kelurahan Tunggulwulung Kecamatan Lowokwaru. Metode: Penelitian ini menggunakanan metode observasional dengan pendekatan cross sectional. Sampel penelitian berjumlah 50 responden (25 lansia yang aktif dan 25 lansia tidak aktif). Teknik penelitian purposive quota sampling dengan analisa data menggunakan uji Chi-Square. Hasil Dari hasil penelitian didapatkan nilai $\rho: 0,006 ; \alpha$ : 0,05 . Karena $\rho<\alpha$ maka Ho ditolak artinya terdapat perbedaan yang signifikan pada tingkat Activity of Daily Living antara lansia aktif dengan lansia tidak aktif melakukan kunjungan ke posyandu lansia. Kesimpulan: Hasil penelitian ini diharapkan dapat memberikan motivasi kepada lansia bahwa melakukan kunjungan ke posyandu lansia merupakan bentuk kegiatan untuk mengontrol, mempertahankan, dan meningkatkan kesehatan lansia yang diadakan 1 bulan sekali di posyandu setempat.

Kata kunci : Activity of Daily Living (ADL), Lansia, Posyandu Lansia

\section{PENDAHULUAN}

Lanjut usia atau lansia merupakan seseorang yang telah memasuki usia 60 tahun keatas. Lansia merupakan kelompok umur pada manusia yang telah memasuki tahapan akhir dari fase kehidupannya. Kelompok yang dikategorikan lansia ini akan terjadi suatu proses yang disebut Aging Process atau proses penuaan (Notoatmodjo, 2014).

Aktivitas kehidupan harian yang biasanya dilakukan tanpa bantuan orang lain dapat dikatakan sebagai Activity of Daily Living atau dalam istilah bahasa inggris di singkat $A D L$ merupakan kegiatan melakukan pekerjaan rutin sehari-hari. $A D L$ antara lain: ke toilet, makan, berpakaian (berdandan), mandi, dan berpindah tempat.

Proses penuaan penduduk tercepat di Asia Tenggara salah satunya adalah Indonesia. Menurut laporan data demografi penduduk Internasional yang dikeluarkan oleh Bureu of the Cencus (USA) dilaporkan bahwa Indonesia pada tahun 1990-2025 akan mempunyai kenaikan jumlah lanjut usia sebesar $414 \%$, suatu angka paling tinggi diseluruh dunia. Sebagai perbandingan Kenya 347\%, Brazil
$255 \%$, India $242 \%$, China $220 \%$, Jepang $129 \%$, Jerman $66 \%$ dan Swedia 33\% (Boedhi dan Darmojo, 2011).

Populasi lansia di dunia dari tahun ke tahun semakin meningkat, bahkan pertambahan lansia menjadi yang paling mendominasi apabila dibandingkan dengan pertambahan populasi penduduk pada kelompok usia lainnya. Data World Population Prospects tahun 2015 ada 901 juta orang berusia 60 tahun atau lebih yang terdiri atas $12 \%$ dari jumlah populasi global. Pada tahun 2015 dan 2030, jumlah orang berusia 60 tahun atau lebih diproyeksikan akan tumbuh sekitar 56\%, dari 901 juta menjadi 1,4 milyar, dan pada tahun 2050 populasi lansia diproyeksikan lebih dari 2 kali lipat di tahun 2015, yaitu mencapai 2,1 milyar (United Nations, 2015). Pada tahun 2018, dari total jumlah populasi di Jawa Timur, terdapat 11,80\% penduduk lansia. Angka tersebut lebih tinggi dibanding proporsi lansia di tingkat nasional yaitu sekitar 8,03 persen (BPS Jawa Timur, 2016). Menurut hasil Sensus 2018 Populasi lanjut usia Kabupaten Malang termasuk cukup tinggi karena jumlah lanjut usia umur 60 tahun Kota Malang mencapai $8.5 \%$. Persentase 


\section{PROFESIONAL HEALTH JOURNAL}

Volume 1, No. 2, Juni 2020 (Hal. 58-64)

Available Online at https://www.ojsstikesbanyuwangi.com

tersebut lebih tinggi dibanding persentase nasional yang hanya mencapai $7.6 \%$. Hal tersebut terjadi karena semakin meningkatnya usia harapan hidup, di mana usia harapan hidup Kota Malang sudah mencapai 65 tahun (BPS Jawa Timur, 2016).

\section{METODE}

Penelitian ini merupakan penelitian kuantitatif dengan pendekatan crosssectional. Penelitian ini dilakukan di Kelurahan Tunggulwulung Kecamatan Lowokwaru. Teknik sampling yang digunakan adalah purposive quota sampling dan melibatkan sampel sebanyak 50 responden yang memenuhi kriteria:

a. Kriteria Inklusi

1. Lansia berumur 60 - 90 tahun

2. Bertempat tinggal di Kelurahan Tunggulwulung

3. Lansia dalam keadaan kondisi fisik dan mental yang sehat

4. Lansia yang kooperatif

5. Bersedia menjadi responden.

b. Kriteria Eksklusi

1. Lansia sedang sakit

2. Lansia yang mengalami gangguan status mental

3. Lansia yang mengalami gangguan kognitif

4. Lansia tidak berada di tempat saat pengambilan data

Instrumen yang digunakan dalam penelitian ini adalah KMS (Kartu Menuju Sehat) dan lembar observasi indeks katz yang sudah terstandarisasi.

HASIL

Tabel 1. Karakteristik Responden

\begin{tabular}{lccc}
\hline $\begin{array}{l}\text { Karakteristik } \\
\text { Responden }\end{array}$ & Jml Lansia & \multicolumn{2}{c}{$\%$} \\
\hline
\end{tabular}

Jenis Kelamin

\begin{tabular}{|c|c|c|c|c|}
\hline $\begin{array}{l}\text { Laki-laki } \\
\text { Perempuan }\end{array}$ & $\begin{array}{c}4 \\
21\end{array}$ & $\begin{array}{l}11 \\
14\end{array}$ & $\begin{array}{l}8 \\
42\end{array}$ & $\begin{array}{l}22 \\
28\end{array}$ \\
\hline Total & 25 & 25 & 50 & 50 \\
\hline \multicolumn{5}{|l|}{ Umur } \\
\hline $60-69$ thn & 20 & 15 & 40 & 30 \\
\hline$>70$ thn & 5 & 10 & 10 & 20 \\
\hline Total & 25 & 25 & 50 & 50 \\
\hline \multicolumn{5}{|l|}{ Agama } \\
\hline Islam & 25 & 25 & 50 & 50 \\
\hline Selain Islam & - & - & - & - \\
\hline Total & 25 & 25 & $\mathbf{5 0}$ & 50 \\
\hline \multicolumn{5}{|l|}{ Suku } \\
\hline Jawa & 25 & 25 & 50 & 50 \\
\hline Madura & - & - & - & - \\
\hline Total & 25 & 25 & 50 & 50 \\
\hline \multicolumn{5}{|c|}{ Pendidikan } \\
\hline Tidak sekolal & h 4 & 10 & 8 & 20 \\
\hline $\mathrm{SD}$ & 14 & 8 & 28 & 16 \\
\hline SMP & 2 & 5 & 4 & 10 \\
\hline SMA & 3 & 2 & 6 & 4 \\
\hline $\mathrm{PT}$ & 2 & - & 4 & - \\
\hline Total & 25 & 25 & 50 & 50 \\
\hline \multicolumn{5}{|l|}{ Pekerjaan } \\
\hline Tdk bekerja & 14 & 12 & 28 & 24 \\
\hline Petani & 5 & 9 & 10 & 18 \\
\hline Pedagang & 4 & 4 & 8 & 8 \\
\hline PNS & 2 & - & 4 & - \\
\hline Total & 25 & 25 & 50 & 50 \\
\hline
\end{tabular}

\section{Perkawinan}

$\begin{array}{lllll}\text { Menikah } & 14 & 18 & 28 & 36\end{array}$

Janda / Duda $11 \quad 7 \quad 14$

$\begin{array}{lllll}\text { Total } & 25 & 25 & 50 & 50\end{array}$

Berdasarkan Tabel 1 menunjukkan bahwa proporsi karakteristik responden berdasarkan umur responden, jumlah terbanyak yaitu pada kelompok umur 6069 tahun baik pada lansia yang aktif mengikuti posyandu sebanyak 20 orang (40\%) maupun tidak aktif mengikuti posyandu sebanyak 15 orang (30\%). Jenis kelamin responden, didapatkan jumlah terbanyak yaitu jenis kelamin perempuan sebanyak 21 orang (42\%) pada lansia aktif

Srisuharny, M., dkk., Perbedaan Tingkat Activity of Daily Living 


\section{PROFESIONAL HEALTH JOURNAL}

Volume 1, No. 2, Juni 2020 (Hal. 58-64)

Available Online at https://www.ojsstikesbanyuwangi.com

mengikuti posyandu dan 14 orang (28\%) pada lansia yang tidak aktif mengikuti posyandu.Diketahui pula pada tabel 1 responden menganut $100 \%$ agama Islam, dapat di lihat juga suku responden baik lansia yang aktif maupun tidak aktif mengikuti posyandu lansia adalah mayoritas suku Jawa yaitu 50 orang (100\%). Tingkat pendidikan responden, hampir setengahnya yaitu tingkat SD 14 orang $(28 \%)$ pada lansia yang aktif. Pada status pekerjaan responden hampir setengahnya tidak bekerja yaitu 14 orang (28\%) pada lansia yang aktif dan 12 orang (24\%) pada lansia tidak aktif, sedangkan pada status perkawinan, didapatkan mayoritas adalah menikah yaitu 16 orang $(32 \%)$ pada lansia yang tidak aktif mengikuti posyandu.

Table 2. Hasil Analisa Univariat.

\begin{tabular}{|c|c|c|c|c|}
\hline \multirow{2}{*}{$\begin{array}{l}\text { Tingkat } \\
\text { kemandirian } \\
A D L\end{array}$} & \multicolumn{2}{|c|}{ Aktif } & \multicolumn{2}{|c|}{ Tidak aktif } \\
\hline & $\mathrm{f}$ & $\%$ & $\mathrm{f}$ & $\%$ \\
\hline Mandiri & 21 & 84 & 8 & 32 \\
\hline Ketergantungan & 4 & 16 & 17 & 68 \\
\hline Total & 25 & 100 & 25 & 100 \\
\hline
\end{tabular}

Berdasarkan Tabel 2 data yang diperoleh melalui kuesioner indeks katz pada responden di Posyandu Srikandi RW 05 Kelurahan Tunggulwulung Kecamatan Lowokaru, menunjukkan bahwa dari 25 responden tingkat $A D L$ pada lansia aktif yang melakukan kunjungan ke posyandu sebagian besar tergolong mandiri yaitu 21 orang $(84 \%)$ dan 4 orang $(16 \%)$ lainnya mengalami ketergantungan.

Selanjutnya untuk tingkat $A D L$ pada lansia yang tidak aktif melakukan kunjungan ke posyandu lansia, menunjukan bahwa dari 25 responden tingkat $A D L$ pada lansia yang tidak aktif melakukan kunjungan ke posyandu sebagian besar tergolong ketergantungan yaitu 17 orang $(68 \%)$ dan 8 orang $(32 \%)$ yang mandiri.

Tabel 3. Hasil Analisa Bivariat

\begin{tabular}{llllllll}
\hline \multirow{2}{*}{$\begin{array}{l}\text { Tingkat } \\
\text { Kemandir } \\
\text { ian } \boldsymbol{A} \boldsymbol{D} \boldsymbol{L}\end{array}$} & \multicolumn{4}{c}{ Keikutsertaan } & \multicolumn{2}{c}{ Total } \\
\cline { 2 - 7 } & \multicolumn{4}{c}{ Aktif } & \multicolumn{4}{c}{ Tidak aktif } \\
\cline { 2 - 7 } & $\mathrm{n}$ & $\%$ & $\mathrm{n}$ & $\%$ & $\mathrm{n}$ & $\%$ \\
\hline Mandiri & 21 & 42 & 8 & 16 & 29 & 58 \\
\hline Ketergantu & 4 & 8 & 17 & 34 & 21 & 42 \\
ng & & & & & & \\
\hline Total & $\mathbf{2 5}$ & $\mathbf{5 0}$ & $\mathbf{2 5}$ & $\mathbf{5 0}$ & $\mathbf{5 0}$ & $\mathbf{1 0 0}$ \\
\hline$\chi 2$ hitung & $: 10,119$ & & & & \\
$\chi 2$ tabel & $: 3,84$ & & & & \\
P Value & $: 0,006$ & & & & \\
A & $: 0,05$ & & & &
\end{tabular}

Tabel 3 menunjukkan bahwa hasil analisis perbedaan tingkat Activity of Daily Living antara lansia aktif dengan lansia tidak aktif melakukan kunjungan ke posyandu lansia diketahui bahwa responden yang aktif mengikuti posyandu lebih banyak yang mandiri yaitu 21 orang (42\%), sedangkan 4 orang $(8 \%)$ mengalami ketergantungan.Pada responden yang tidak aktif melakukan kunjungan ke posyandu diketahui sebanyak 8 orang (16\%) yang mandiri dan 17 orang (34\%) tergolong dalam ketergantungan.

Hasil uji statistik diperoleh $\chi^{2}$ hitung sebesar 10,119 sehingga lebih besar dari

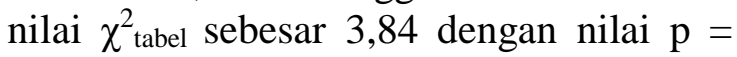
0,006 yang berarti untuk nilai $\mathrm{P}$ valuenya $<$ $\alpha$, yaitu dengan $\alpha=0,05$. Hasil analisis ini membuktikan bahwa ada perbedaan signifikan tingkat Activity of Daily Living pada lansia aktif dengan lansia tidak aktif melakukan kunjungan ke posyandu lansia".

\section{PEMBAHASAN}

Posyandu lansia adalah pos pelayanan terpadu untuk masyarakat usia lanjut di suatu wilayah tertentu yang sudah disepakati, yang digerakkan oleh masyarakat dimana mereka biasa 


\section{PROFESIONAL HEALTH JOURNAL}

Volume 1, No. 2, Juni 2020 (Hal. 58-64)

Available Online at https://www.ojsstikesbanyuwangi.com

mendapatkan pelayanan kesehatan (Ismawati, 2010).Hasil penelitian diketahui bahwa keberadaan posyandu sangat berdampak positif bagi lansia, dimana kegiatan-kegiatan yang ada di posyandu sangatlah bermanfaat bagi lansia. Hal ini dibuktikan dengan tingginya tingkat kemandirian lansia yang masih berperan aktif dalam mengikuti kegiatan posyandu. Kegiatan posyandu lansia yang berjalan dengan baik akan memberi kemudahan bagi lansia dalam mendapatkan pelayanan kesehatan dasar, sehingga kualitas hidup lansia tetap terjaga dengan baik dan optimal salah satunya dengan memanfaatkan posyandu. Pemanfaatan posyandu lansia dapat dikatakan bermanfaat atau berhasil apabila lansia dapat mengontrol kesehatannya sendiri khususnya dalam Activity of Daily Living secara mandiri.

Activity of Daily Living (ADL) merupakan suatu bentuk kemampuan seseorang untuk melakukan aktivitas sehari-hari secara mandiri. Penentuan kemandirian fungsional dapat mengidentifikasi kemampuan dan keterbatasan klien sehingga memudahkan pemilihan intervensi yang tepat (Maryam, 2012). $A D L$ meliputi aktivitas yang penting untuk perawatan pribadi meliputi makan, eliminasi, transfering, pergi ke kamar mandi, berpakian dan mandi (Agung, 2012)

Terdapat sejumlah alat atau instrument ukur yang telah teruji validitasnya untuk mengukur $A D L$ dasar salah satunya adalah indeks $A D L$ Katz. Skala $A D L$ dasar ini sangat bermanfaat dalam menggambarkan status fungsional dasar dan menentukan target yang ingin dicapai untuk pasien-pasien dengan derajat gangguan fungsional yang tinggi, terutama pada pusat-pusat rehabilitasi. Tujuan Indeks $A D L$ Katz adalah untuk mengidentifikasi defisit status fungsional dasar dan mencoba memperoleh cara Srisuharny, M., dkk., Perbedaan Tingkat Activity of Daily Living mengatasi dan memperbaiki status fungsional dasar tersebut. Skor $A D L$ dasar dari setiap pasien lansia harus diikuti dan dipantau secara berkala/ periodik untuk melihat apakah terjadi perburukan atau perbaikan (Setiati, 2015).

Lansia merupakan kelompok umur pada manusia yang telah memasuki tahapan akhir dari fase kehidupannya. Kelompok yang dikategorikan lansia ini akan terjadi suatu proses yang disebut Aging Process atau proses penuaan. Menua bukanlah suatu penyakit tetapi merupakan proses berkurangnya daya tahan tubuh dalam menghadapi rangsangan dalam maupun luar tubuh. Akibat adanya rangsangan tersebut dapat mempengaruhi kesehatan fisik lansia yang menyebabkan lansia menjadi tergantung kepada orang lain. Keterbatasan fisik pada lansia tersebut menyebabkan keterbatasan dalam melakukan Activity of Daily Living, sehingga lansia akan sering memerlukan bantuan orang lain yang akan mempengaruhi tingkat kemandirian lansia. (Notoatmodjo, 2014).

Hasil analisis menunjukkan bahwa terdapat perbedaan tingkat Activity of Daily Living $(A D L)$ antara lansia aktif dengan lansia tidak akif melakukan kunjungan ke posyandu lansia di Kelurahan Tunggulwulung Kecamatan Lowokwaru.

Hasil uji dengan nilai $\mathrm{p}=0,006$ yang berarti untuk nilai $\mathrm{P}$ valuenya $<\alpha$, yaitu dengan $\alpha=0,05$ tersebut memberi pengertian bahwa keberadaan posyandu memberikan suatu perubahan yang sangat berarti pada kehidupan lansia, khususnya pada tingkat kemandirian lansia. Tingkat kemandirian lansia ini memberi arti dimana lansia yang aktif mengikuti posyandu memiliki tingkat kemandirian yang lebih baik dibandingkan dengan lansia yang tidak aktif mengikuti posyandu. Hal ini dikarenakan lansia yang aktif ke posyandu rutin mendapatkan pelayanan kesehatan dasar sebulan sekali 


\section{PROFESIONAL HEALTH JOURNAL}

Volume 1, No. 2, Juni 2020 (Hal. 58-64)

Available Online at https://www.ojsstikesbanyuwangi.com

selama setahun, sehingga kesehatan fisiknya juga lebih baik dari pada lansia yang tidak aktif mengikuti posyandu (Ismail, 2015).

Hasil dan pembahasan yang telah dijabarkan tersebut dapat diketahui bahwa tingkat acitivity of daily living pada lansia yang aktif mengikuti posyandu sangatlah berbeda dengan lansia yang tidak aktif mengikuti posyandu. Pada 21 orang $(84 \%)$ lansia yang aktif mereka memiliki tingkat kemandirian lebih tinggi karena dalam pelaksanaan posyandu di RW 05 Kelurahan Tunggulwulung Kecamatan Lowokwaru menerapkan sistem 5 meja yaitu : meja 1 sebagai tempat pendaftaran, disini kader akan mendata setiap lansia yang datang ke posyandu. Meja 2 tempat penimbangan dan pencatatan berat badan, kader akan menimbang berat badan dan tinggi badan lansia lalu mencatatnya dalam buku dan KMS. Meja 3 tempat pemeriksaan, petugas kesehatan melakukan pemeriksaan $A D L$, pengukuran tekanan darah dan mendapatkan pengobatan jika lansia mempunyai keluhan. Meja 4 tempat penyuluhan tentang gizi, pola hidup sehat, dan kesehatan lansia. Edukasi kepada lanjut usia merupakan bentuk pembekalan beberapa informasi tertentu yang membantu dalam perawatan kesehatan, membantu meningkatkan kepatuhan keperawatan dan pengobatan.Edukasi obat, misalnya meliputi nama obat, untuk apa, mengapa diberikan, bagaimana dan kapan harus diberikan, apa efeknya, efek samping apa yang terjadi, dan apa yang harus dilakukan jika ada dosis yang terlewatkan.

Dari uraian di atas dapat disimpulkan bahwa pentingnya ada dukasi atau pendidikan kesehatan pada lanjut usia secara optimal untuk memberikan jalan keluar seputar masalah kesehatan yang di alami lanjut usia. Dengan adanya edukasi kesehatan pada lansia di posyandu lansia akan menjadi lebih mandiri dalam Srisuharny, M., dkk., Perbedaan Tingkat Activity of Daily Living memelihara kesehatannya. Penyuluhan kesehatan juga sangat berpengaruh pada tingkat pengetahuan pasien lansia yang rata-rata masih kurang tentang manfaat posyandu lansia, yang pada akhirnya berpengaruh pada sikap yang menentukan akan hadir tidaknya lansia pada posyandu lansia, meja 5 tempat memberikan informasi. Lansia yang aktif mengikuti posyandu secara rutin akan mendapatkan semua pelayanan yang ada sehingga mampu meningkatkan kesehatan fisiknya dengan begitu lansia akan lebih mandiri dalam melakukan aktivitas sehari-hari.

Sedangkan 5 responden (20\%) lansia tidak aktif yang mengalami ketergantungan, mengatakan jarang ikut posyandu karena jarak rumah dan tempat diadakannya posyandu terlalu jauh sehingga lansia menjadi malas untuk ikut posyandu. Ketidakaktifan lansia juga dipengaruhi oleh beberapa faktor yang menyebabkan lansia tidak aktif seperti faktor fisik lansia dan pengetahuan lansia. Kondisi fisik yang lemah akan membuat seseorang merasa tidak leluasa untuk memanfaatakan pelayanan kesehatan dan sarana prasarananya sedangkan pengetahun lansia yang rendah juga mempengaruhi ketidakaktifan lansia karena mereka tidak mengetahui atau mengerti tentang posyandu lansia.

\section{KESIMPULAN}

1. Pebedaan tingkat Activity of Daily Living antara lansia aktif dengan lansia tidak aktif melakukan kunjungan keposyandu lansia di Kelurahan Tunggulwulung Kecamatan Lowokwaru didapatkan hasil dari 25 responden yang aktif melakukan kunjungan ke posyandu sebagian besar adalah tergolong mandiri yaitu 21 orang (84\%) dan 4 orang (16\%) yang mengalami ketergantungan, sedangkan tingkat Activity of Daily 


\section{PROFESIONAL HEALTH JOURNAL}

Volume 1, No. 2, Juni 2020 (Hal. 58-64)

Available Online at https://www.ojsstikesbanyuwangi.com

Living dari 25 responden yang tidak aktif melakukan kunjungan keposyandu sebagian besar adalah tergolong ketergantungan yaitu 17 orang (68\%)dan $8(32 \%)$ lainnya mandiri. Ada perbedaan tingkat Activity Daily of Living $(A D L)$ antara lansia aktif dengan lansia tidak aktif melakukan kunjungan ke posyandu lansia di Kelurahan Tunggulwulung Kecamatan Lowokwaru dengan hasil uji statistic nilai $\mathrm{p}=0,006$ yang berarti untuk nilai $\mathrm{P}$ valuenya $<\alpha$, yaitu dengan $\alpha=0$

2. Ada perbedaan tingkat Activity Daily of Living $(A D L)$ antara lansia aktif dengan lansia tidak aktif melakukan kunjungan ke posyandu lansia di Kelurahan Tunggulwulung Kecamatan Lowokwaru dengan hasil uji statistic nilai $\mathrm{p}=0,006$ yang berarti untuk nilai $\mathrm{P}$ valuenya $<\alpha$, yaitu dengan $\alpha=0$.

\section{SARAN}

Bagi Seluruh Lansia diharapkan aktif dalam melakukan kunjungan ke posyandu untuk mempertahankan tingkat kemandirian dalam melakukan aktivitas sehari-hari dan Kader Posyandu di diharapkan lebih meningkatkan lagi kesadaran lansia tentang keaktifan lansia dalam pentingnya melakukan kunjungan ke posyandu lansia. Kader hendaknya selalu memberikan pengetahuan dan kesadaran kepada lansia untuk lebih aktif dalam mengikuti kegiatan posyandu lansia.

\section{DAFTAR PUSTAKA}

Agung, I (2012). Uji Keandalan dan Kesahihan Indeks Activity of Daily
Living Barthel untuk Mengukur Status Fungsional Dasar pada Lanjut Usia di RSCM. Tesis. Jakarta; Program Study Ilmu Penyakit Dalam Fakultas Kedokteran Universitas Indonesia. Diakses pada tanggal 31 Mei 2017 dari http://www.eprint.lib.ui.ac.id

Badan Pusat Statistik. (2016). Statistik Penduduk Usia Lanjut 2016. Jakarta : Badan Pusat Statistik.

Boedhi, Darmojo, R. (2011). Buku Ajar Ilmu Kesehatan Lanjut Usia. Edisi 4. Jakarta : Balai Penerbit FKUI.

Ismawati, dkk. (2010). Posyandu dan Desa Siaga panduan untuk Bidan dan Kader. Yogyakarta : Nuha Medika.

Ismail, S.O., Kasim, V.N., Ilham,R. (2015). Faktor-Faktor yang Mempengaruhi Kemandirian Lansia di Panti Sosial Tresna Werdha Provinsi Gorontalo. Vol. 3. No. 3

Notoatmojo,S. (2014). Metodologi penelitian kesehatan. Jakarta: Rineka Cipta.

Maryam, R. Siti, dkk. (2012). Ilmu Kesehatan Gerontik Edisi 3.Jakarta; Salemba.

Setiati, (2015). Pedoman Praktis Perawatan Kesehatan Untuk Mengasuh Orang Lanjut usia. Jakarta: PKUI

United Nations. (2015). World Population Ageing.http://www.un.org/en/developm ent/desa/population/publications/pdf/ag eing/WPA2015.Highlights.pdf.

Diakses tanggal 10 Oktober 2017 